\title{
Field Study on the Thermal Performance of Vacuum Tube Solar Collectors in the Climate Conditions of Western Norway
}

\author{
Victoria Popsueva ${ }^{1}$, Andrés Franklin Olivares Lopez ${ }^{1}$, Anna Kosinska ${ }^{1}$ and Oleg Nikolaev ${ }^{2,3}$ \\ and Boris V. Balakin 1,2,* \\ 1 Western Norway University of Applied Sciences, Inndalsveien 28, 5063 Bergen, Norway; \\ Victoria.Popsueva@hvl.no (V.P.); Andres.Olivares@hvl.no (A.F.O.L.); Anna.Dorota.Kosinska@hvl.no (A.K.) \\ 2 National Research Nuclear University MEPhI (Moscow Engineering Physics Institute), Kashirskoe Shosse 31, \\ 115409 Moscow, Russian; Oleg.Nikolaev@skoltech.ru \\ 3 Skolkovo Institute of Science and Technology, Bolshoy Boulevard 30, bld. 1, 121205 Moscow, Russia \\ * Correspondence: Boris.Balakin@hvl.no
}

check for updates

Citation: Popsueva, V.; Lopez, A.F.O.; Kosinska, A.; Nikolaev, O.; Balakin, B.V. Field Study on the Thermal Performance of Vacuum Tube Solar Collectors in the Climate Conditions of Western Norway. Energies 2021, 14, 2745. https:// doi.org/10.3390/en14102745

Academic Editor: Jürgen Heinz Werner

Received: 6 April 2021

Accepted: 6 May 2021

Published: 11 May 2021

Publisher's Note: MDPI stays neutral with regard to jurisdictional claims in published maps and institutional affiliations.

Copyright: (C) 2021 by the authors Licensee MDPI, Basel, Switzerland. This article is an open access article distributed under the terms and conditions of the Creative Commons Attribution (CC BY) license (https:// creativecommons.org/licenses/by/ $4.0 /)$

\begin{abstract}
A significant part of energy consumption in Northern countries goes to heating. There is no consensus about the most efficient source of renewable heat there. This paper presents a field study for a $7.8 \mathrm{~m}^{2}$ vacuum tube solar collector facility that is conservatively located in the cloudy and cold climate conditions of western Norway. We analyse a year-long operation by examining the rig's statistics. We show that in Nordic latitudes with rainy climate conditions, a domestic solar hot water system can produce $2200 \mathrm{kWh}_{t h} / \mathrm{y}$ at a thermal efficiency of up to $72 \%$. The average amount of heat produced by the collectors was up to $14.7 \mathrm{kWh}_{t h} / \mathrm{d}$. This was enough to sustain the domestic hot water demand in an average Norwegian household for 6 months with a short period of auxiliary heating. In conclusion, we calculated that a $3 \times$ upscaled area facility would deliver over $25 \mathrm{kWh}_{t h}$ covering six months of total heat consumption. The payback period for the facility is 12 years.
\end{abstract}

Keywords: solar collector; vacuum tube solar collector; Norway; field study; solar domestic hot water system

\section{Introduction}

According to the International Energy Agency, in 2018, about half of the total end consumption of energy was related to residential and industrial heating. Of the total household energy consumption, space and water heating can take up to $80 \%$, according to Eurostat data from 2016 [1]. Increasing the share of renewables such as solar thermal energy in residential heating can be one of many steps towards achieving energy savings.

A recent comprehensive analysis of large-scale solar thermal systems in countries where the technology is utilised most (Denmark, China, Germany, and Austria) is presented in [2]. One of the main findings is the importance of incentive policies provided by countries' governments. Another significant success factor is the existence of infrastructure of large-scale heating systems. Denmark's case is particularly interesting with respect to current research focused on solar thermal technology in Western Norway. All the countries mentioned above have more favourable solar heating conditions because of their geographic location and climate conditions. Denmark's case is close enough for comparison with Norway, both in climate and population patterns. In Denmark, solar district heating $(\mathrm{SDH})$ utilities play a crucial role in successfully implementing solar thermal systems. By 2018, there were 118 plants in operation with a total capacity of $970 \mathrm{MW}$, which comprises $63 \%$ worldwide capacity of large-scale solar thermal systems [2]. Denmark's success relies on several key factors, such as widespread SDH networks which connect to over $60 \%$ of Danish households, and efforts to reduce individual heating, such as the ban on installing oil- and gas-fired boilers. Government taxation policies lead to gas and other fossil fuels prices to be among highest in Europe, making solar thermal systems 
competitive at around 70-80 Euro/MWh. Although the SDH facilities in Denmark deliver $400-460 \mathrm{kWh}_{t h} / \mathrm{m}^{2}$ [3], which is a rather significant amount of solar heat in Scandinavia, the average efficiency of the solar collectors is at a low level of $40 \%$ [3]. This is related to the fact that the facilities are equipped with outdated flat-plate collectors. As it follows from multiple studies on the subject, the nanofluids can boost the efficiency of the collectors when used there instead of the conventional coolants [4-6]. Therefore, it is possible to modernize the existing SDH facilities.

Another factor is prices at SDH utility locations-they tend to be built close to small communities where prices are lower than large city centres. Since the 1990s, the Danish government has been rolling out various programs such as investment subsidies, premium tariffs to encourage SDH utilities operating on the energy market, and an "energy savings credits" market, similar to carbon emission trading system [2].

Over 90\% of Norway's electricity is produced by hydropower facilities [7], making hydroelectricity cheap and readily available for domestic heating purposes. An average household electricity price was $0.1 \mathrm{Euro} / \mathrm{kWh}_{e l}$ in 2021, including energy price, rent of network, and taxes. This might be the main reason why solar thermal heating has not attained a significant share of the market. However, the situation is about to change due to Norway's increasing investment in offshore facilities and harbours, and explosive growth in electric vehicles, personal cars, and collective transport vehicles such as buses and ferries [8]. At the same time, there are very few hydropower resources left to harvest. Using high-quality energy such as electricity to heat residential buildings becomes less cost-effective, thus solar heat may be a viable alternative.

Several Norwegian studies and simulations have been conducted using small-scale model passive houses. Hagos et al. [9] assess the possibility of solar water heating in residential housing in inland Norway. Based on the meteorological data, a daily solar radiation average of $2.21 \mathrm{kWh} / \mathrm{m}^{2}$ is observed for this location. These values should be close enough to Western Norway to allow direct comparison. Average summer temperatures are around $15-18{ }^{\circ} \mathrm{C}$, and average winter temperatures are considerably cold, around -3 to $-4{ }^{\circ} \mathrm{C}$ [10]. The simulation assumed a household annual domestic hot water demand of $5 \mathrm{MWh}$. Two types of solar collectors were considered: tubular and flat plate glazed collectors. The results show that such collectors may supply $48 \%$ (glazed collectors) to $62 \%$ (vacuum tube collectors) of the domestic hot water demand. Vacuum tube collectors appear to be more suitable for Norway, with cold outdoor temperatures and cloudy weather.

Solar domestic hot water systems compete with photovoltaic (PV) systems and heat pumps for their share of the renewable energy market. According to the Norwegian Central Statistical Bureau [7], heat pumps deliver $10.5 \%$ of total district heating production in 2019. A comparison of the energy consumption in two passive houses in Oslo, one with a solar heating system and one with an air-water heat pump, is shown in [11,12]. These studies provide measurements of the total heating demand. Both houses have a heated floor area of $116 \mathrm{~m}^{2}$ and a calculated space heating demand of $23 \mathrm{kWh} / \mathrm{m}^{2}$ assuming an indoor temperature of $20{ }^{\circ} \mathrm{C}$. Energy used for the production of domestic hot water equals $3480 \mathrm{kWh}_{t h} / \mathrm{y}$. The solar collector used in the project has an area of $18.9 \mathrm{~m}^{2}$. The coolant is pure water, the heat storage is a tank of $800 \mathrm{~L}$, and there is also a $100 \mathrm{~L}$ pressurised vessel to hold domestic hot water. There is an additional $76 \mathrm{~L}$ boiler in both houses, switched on when the solar heat is insufficient. Since the solar thermal system is switched off during the winter months, a direct comparison between the two systems may only be made during the spring/summer months. The two houses and their orientations concerning the sun and shade were not identical, and also the consumption of hot water was different. Still, it was estimated that electricity consumption was $15 \%$ lower in the solar heated house, where solar energy provided around $2600 \mathrm{kWh} / \mathrm{y}$. This comparison shows that solar thermal heating is competitive with heat pumps at the considered latitude and requires less additional energy. An important conclusion coming from [11] is that the amount of solar heat produced in Norway is less than in the rest of Scandinavia. For example, in the article 
by Bernardo [13] the solar collectors located in Lund (Sweden) delivered $307 \mathrm{kWh}_{t h} /\left(\mathrm{m}^{2} \mathrm{y}\right)$ while the respective system in Norway [11] produced $137 \mathrm{kWh}_{t h} /\left(\mathrm{m}^{2} \mathrm{y}\right)$.

When it comes to competition with PV systems, the comparison gives less certain results. A simulation study [14] compares performances of separate PV and solar thermal (T) systems to combined PV / T systems. Two types of solar collectors (glazed and unglazed) are used. The simulation model is a residential building with a $160 \mathrm{~m}^{2}$ heated floor area and a total energy demand of $70.2 \mathrm{kWh} / \mathrm{m}^{2}$, of which $20.9 \mathrm{kWh} / \mathrm{m}^{2}$ and $23.8 \mathrm{kWh} / \mathrm{m}^{2}$ goes to space heating and domestic hot water, respectively. The coolant of the solar thermal system was a water-glycol mixture. Results suggest that a high-efficiency PV is closest to achieving a zero-energy balance of the household; the "second best" was the PV/T system. The results show that the highest coverage of on-site energy generation $(73 \%)$ is achieved by the system with high-efficiency PV panels.

Another recent simulation study [15] is investigating two separate systems: a solar thermal (flat plate collector) and a PV system in Narvik, which is located in Northern Norway in subarctic conditions, which makes it a unique example. This study demonstrates that the solar systems meet the demands of space heating and domestic hot water consumption. At the given latitude, this is possible during approximately two summer months due to sun availability for most of the day. During the winter months of October through January, however, the production is zero. Nevertheless, the solar collectors and the PV plates produced around $14,300 \mathrm{kWh}_{t h}$ and $18,600 \mathrm{kWh}_{e l}$ a year, respectively. With current electricity prices and subsidies policies, the solar thermal system becomes profitable after 15 years. The initial investment cost is higher for the PV system, so the payback period is around 20 years.

From the overview above, we conclude that there is no field data to evaluate the potential viability of solar thermal technology in Norway. This article addresses the issue, presenting detailed year-long statistics of field operation for a solar collector facility located in Bergen, Western Norway. Due to its cloudy climate, this region is among the least insolated in Europe at the considered latitude. To our knowledge, in this study, we conduct the first systematic evaluation of the solar thermal technology in such climate conditions.

\section{Methodology}

The solar collector facility is located at the Western Norway University of Applied Sciences (Høgskulen på Vestlandet-HVL), Bergen, Norway. The facility is a part of the Solar Energy Lab launched in 2018 at campus Kronstad $\left(60^{\circ} 22^{\prime} 04.2^{\prime \prime} \mathrm{N} 5^{\circ} 21^{\prime} 03.3^{\prime \prime} \mathrm{E}\right)$. The laboratory consists of the photovoltaic (PV) system with a total area of $9.9 \mathrm{~m}^{2}, 5 \mathrm{~m}^{2}$ solar concentrator from Riza+ [16], a vacuum tube solar collector facility, a greenhouse, a $16.2 \mathrm{~m}^{2}$ custom-designed passive house with balanced ventilation, and a battery bank.

In the present study, we are focused on the thermal performance of the vacuum tube collector system, which is presented in Figure 1. The solar collectors are coupled to a space heating system installed in the greenhouse. 


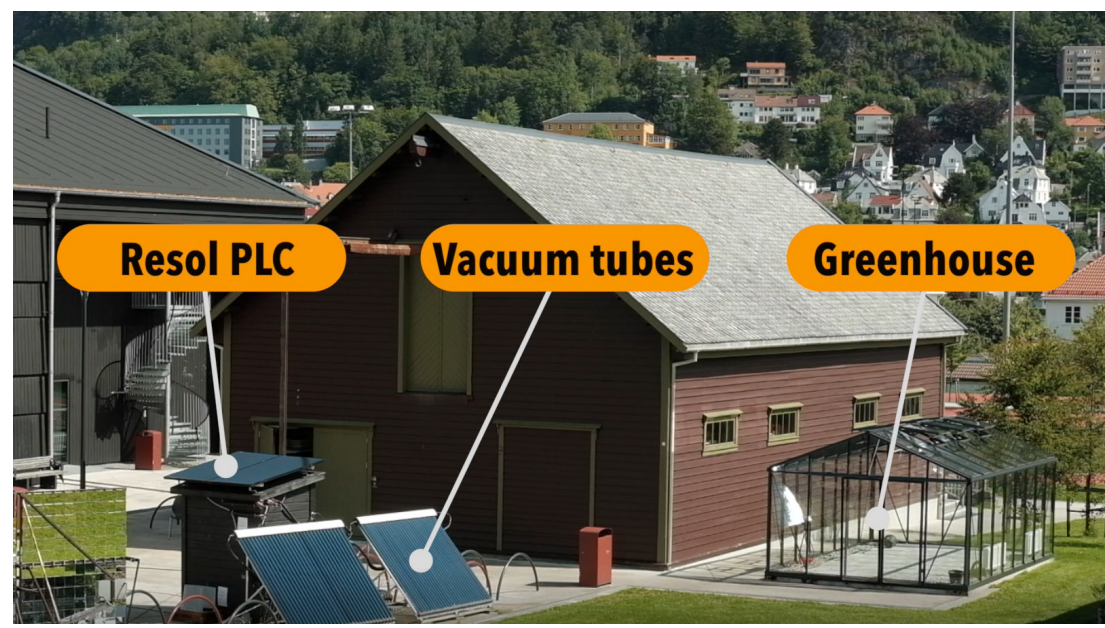

Figure 1. Vacuum tubes in the solar field of Høgskulen på Vestlandet.

The hydraulic scheme of the vacuum tube facility is presented in Figure 2. The solar collector system consists of two Suntask SCM30-58/1800-02 vacuum tube collectors. The effective collector's area is $3.91 \mathrm{~m}^{2}$. The collectors are mounted on the aluminium frames with $45^{\circ}$ tilt angle. The frames are faced towards the south. The ballast of about $60 \mathrm{~kg}$ is placed to the frames' base to prevent the collectors from sliding under the strong wind. The frames were capable of withstanding the wind speed of $26.5 \mathrm{~m} / \mathrm{s}$ in February 2020 [10].

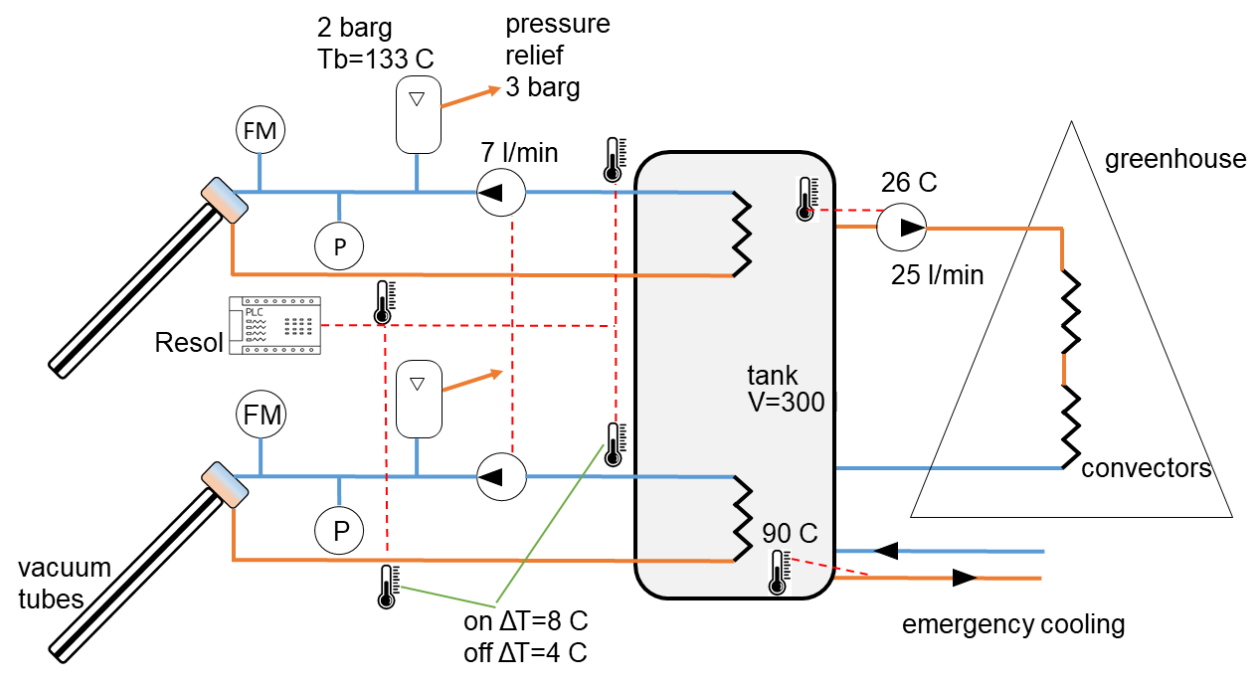

Figure 2. Schematic description of the vacuum tube facility.

The solar collectors deliver captured heat via two independent circulation loops. Each loop is equipped with an equivalent set of flow equipment. The loops consist of the screw pump Star-RS 15/6 from Wilo with a maximum head of $5.5 \mathrm{~m}$ and maximum flow rate of $4.6 \mathrm{~m}^{3} / \mathrm{h}$, the flowmeter Resol V40-15 with the measurement interval 30-50 L/h, and temperature sensors FKP5,5 Pt1000 from Resol with the measurement interval $-50-+180{ }^{\circ} \mathrm{C}$. A propylene glycol-water mixture (1:2) is used in the flow loop as the coolant. The fluid is protected from freezing down to the temperature of $-14{ }^{\circ} \mathrm{C}$. Two expansion vessels are set in the flow loop to keep the system working pressure to 2 barg; the boiling point of the heat transfer fluid is above $130^{\circ} \mathrm{C}$.

A 300-L accumulator tank Sunex Fish S2 acts as a heat storage vessel. The tank is equipped with two identical heat exchangers. The tank contained the propylene glycolwater mixture $(1: 4)$ protected down to $-8{ }^{\circ} \mathrm{C}$. We note the heat exchangers were heated alike as they were mounted at different levels from the bottom (see Figure 2 ). The coefficient 
of heat transfer due to natural convection in the tank was therefore different for the coils. The third pump Yonos PICO 25/1-4 from Wilo was used to deliver the fluid from the tank to the greenhouse that was heated by two thermal convectors. This pump delivers up to $4 \mathrm{~m}$ head, and the maximum flow is $2.7 \mathrm{~m}^{3} / \mathrm{h}$. The $5-\mathrm{m}$ feed line from the tank to the greenhouse was thermally insulated by a $50-\mathrm{mm}$ layer of polyethylene foam with thermal conductivity of $0.04 \mathrm{~W} / \mathrm{mK}$. The Sunex tank acts as the expansion vessel for the greenhouse line.

An automatic control unit SP226 from Resol starts and stops the solar loop pumps based on the temperature difference between the collector and the tank (Figure 2). The startup temperature difference was $8^{\circ} \mathrm{C}$, and the shut-down difference was $4{ }^{\circ} \mathrm{C}$. The temperature settings differed from the default $\left(5 / 10^{\circ} \mathrm{C}\right)$ for SP 226 to enable prolonged thermal energy extraction in poor solar conditions. The temperature difference and the flow rate were recorded and stored by DL3 datalogger from Resol. The interval of data acquisition in the logger was set at $10 \mathrm{~s}$. The logs of the raw collector data are available from the authors.

The pumps in the main collector loops were set at $7 \mathrm{~L} / \mathrm{min}$. The greenhouse-pump was set at $25 \mathrm{~L} / \mathrm{min}$. This pump was activated by a thermal switch at $26{ }^{\circ} \mathrm{C}$. An additional safety system was arranged in the tank to prevent boiling there. The tank was pressurised by 4 barg from a communal cold-water network. The system starts when the tank's temperature rises to $90{ }^{\circ} \mathrm{C}$, and a temperature switch activates a solenoid valve, releasing the fluid to a drainage line and cooling the system. The safety switch had never been in operation during the considered statistical period.

The control and operation system consumed a maximum of $36 \mathrm{~W}$ in operation. The electrical supply came from the PV system of the laboratory. The tank, the pumps, the control station, and the logger were located at a thermally-insulated wooden cabin shown in Figure 1 (under "Resol PLC").

We computed the instantaneous thermal efficiency of the collector from the raw measurements of the flow in the collector loops $Q$ and the temperature difference $\Delta T$ between the tank and the collector [17]:

$$
\eta_{T}=\frac{\rho C_{p} Q \Delta T}{\cos \left(\beta_{a z}\right) \cos \left(45^{\circ}-\beta_{a l}\right) I A(1+\alpha)}
$$

where $\rho$ and $C_{p}$ are the density and the specific heat of the coolant, $A$ is the frontal area of the collector, $\alpha$ is the albedo of the terrain at the site, $I$ is the incident solar heat flux, $\beta_{a l}, \beta_{a z}$ are the altitude and the azimuth angles of the Sun. The data on solar radiation together with the ambient temperature was extracted by two meteorological stations from Bergensværet [18] located close to the experimental site: Kronstad $\left(60^{\circ} 22^{\prime} 31.4^{\prime \prime} \mathrm{N}\right.$ $\left.5^{\circ} 20^{\prime} 52.9^{\prime \prime} \mathrm{E}\right)$ and Nygård $\left(60^{\circ} 23^{\prime} 22.5^{\prime \prime} \mathrm{N} 5^{\circ} 19^{\prime} 48.1^{\prime \prime} \mathrm{E}\right)$. The meteo-station of the University of Bergen [19] $\left(60^{\circ} 23^{\prime} 01.5^{\prime \prime} \mathrm{N} 5^{\circ} 19^{\prime} 54.9^{\prime \prime} \mathrm{E}\right)$ delivered information on the solar angles and the solar radiation. The data from the stations were averaged in space. We ensured correspondence between the data sampling timeline in the collectors and the meteorological data, interpolating them by splines in Matlab. The albedo of the terrain was determined experimentally using the radiometer LS 122 IR (1000-1700 nm, $\left.0.1 \mathrm{~W} / \mathrm{m}^{2}, \pm 10 \%\right)$ from Shenzhen Linshang Technology and the pyranometer SP Lite 2 (400-1100 nm., 1.3 W/m², $\pm 5 \%$ ) from Campbell Scientific. The albedo was determined as $7.4 \pm 1.8 \%$.

The steady-state efficiency for the Suntask collectors is computed according to standard [20]:

$$
\eta=\eta_{0}-a_{1} T_{m}-a_{2} T_{m}^{2} I
$$

where $T_{m}=\Delta T / I$ is the reduced temperature difference between the collector and the ambient conditions, $\eta_{0}=0.735, a_{1}=1.349 \mathrm{~W} /\left(\mathrm{m}^{2} \mathrm{~K}\right), a_{2}=0.015 \mathrm{~W} /\left(\mathrm{m}^{2} \mathrm{~K}^{2}\right)$ [21].

\section{Results and Discussion}

In general, the facility's performance depends on two main factors: available insolation and ambient temperature. Those numbers are presented in Figure 3 in terms of the month- 
average values. Also, the figure presents the statistical dispersion of data within the month. Reading the plot, we note the insolation was below $200 \mathrm{~W} / \mathrm{m}^{2}$ in January-March and October-December. The average temperature was below $10^{\circ} \mathrm{C}$ in this seasons meaning that that temperature difference $\Delta T$ becomes around $70{ }^{\circ} \mathrm{C}$ for a minimum hot-water temperature set in Norway for thermal systems. The thermal loss from the collectors was at the top in autumn-winter. The dispersion of the weather data is observed in the midseason with the largest deviation of insolation of $148 \%$ in November. The insolation started to increase in April, being in the interval $300-400 \mathrm{~W} / \mathrm{m}^{2}$ and approaching the maximum in June 2020. The average ambient temperature altered between $10^{\circ} \mathrm{C}$ and $20^{\circ} \mathrm{C}$. The ambient temperature was relatively stable in summer, while demonstrating a statistical dispersion of $25 \%$.

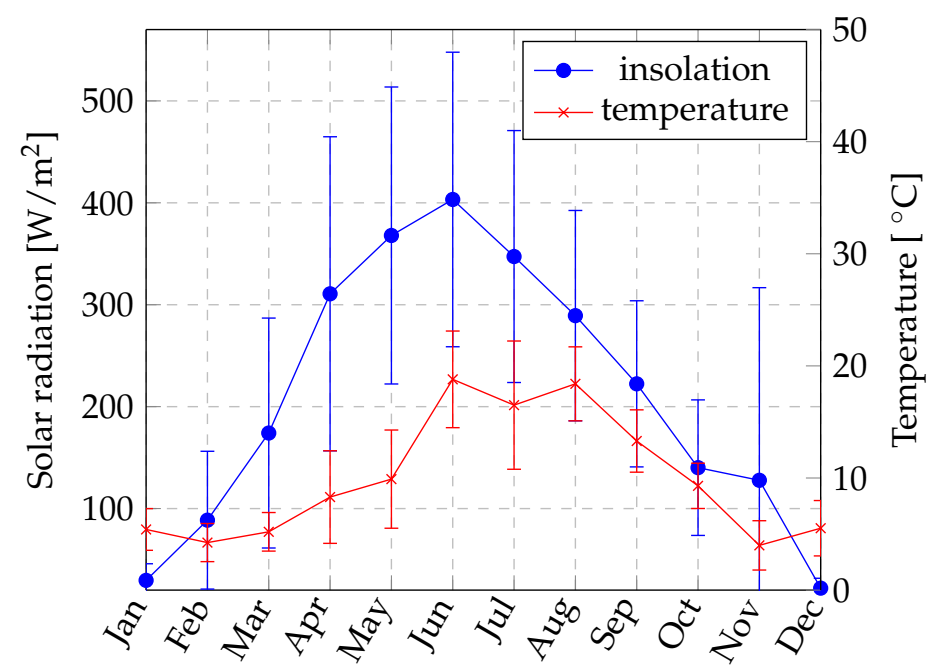

Figure 3. Average insolation and ambient temperature for the considered period.

In Figures 4 and 5 we present the raw collector logs for the selected days of each month. We note the tank was warm enough for the direct use of the hot water in March-October. During this period, the temperature was in the interval $40-60{ }^{\circ} \mathrm{C}$. The tank's temperature was in the desired interval between 3 and $6 \mathrm{~h}$, depending on the month. The facility's most stable operation took place in summer when the pumps were active for most of the day. There was not enough insolation to produce sufficient heat in winter, so the tank remained at the ambient temperature. However, there was a possibility for electrical heating with a supplementary solar heat in February when a limited amount of solar heat was collected, and the temperature rose to about $35^{\circ} \mathrm{C}$.

In terms of heat generation, the collectors generate most of the heat in summer. As can be seen in Figure 6, which demonstrates daily average statistics for the entire year, the collected heat can go up to $25 \mathrm{kWh}_{t h}$. The daily production averaged over each month is presented in Table 1 . The average daily amount of heat is computed in the table as:

$$
\bar{H}=1 / N \sum_{i=1}^{N} \sum_{j=1}^{M_{i}} \rho_{j} C_{p, j} \Delta T_{j} Q_{j}
$$

where $N$ is the number of days in a considered month and index $j$ denotes an instantaneous measurement taken from an array of $M$ points. The size of the array was determined for each day excluding the night measurements by temporal filtering of an acquired 24-h sample. The daytime was determined from the calendar. The thermophysical properties of the water-glycol solution were set dependent of $\Delta T_{j}$ following Alvarez [22]. The instantaneous measurements are available in the table format from the authors. 

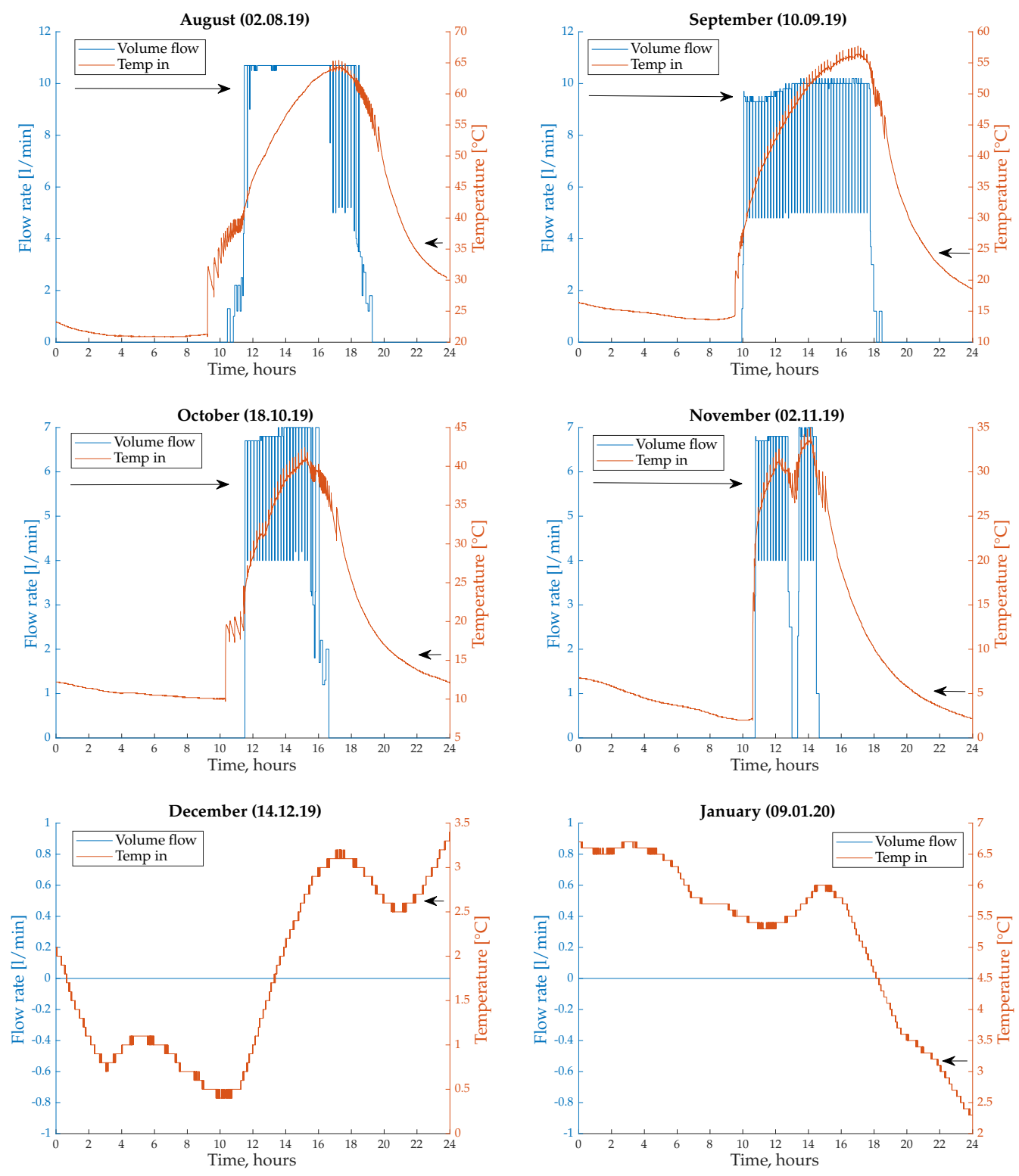

Figure 4. Examples of collector logs for 6 selected dates in August-January. 

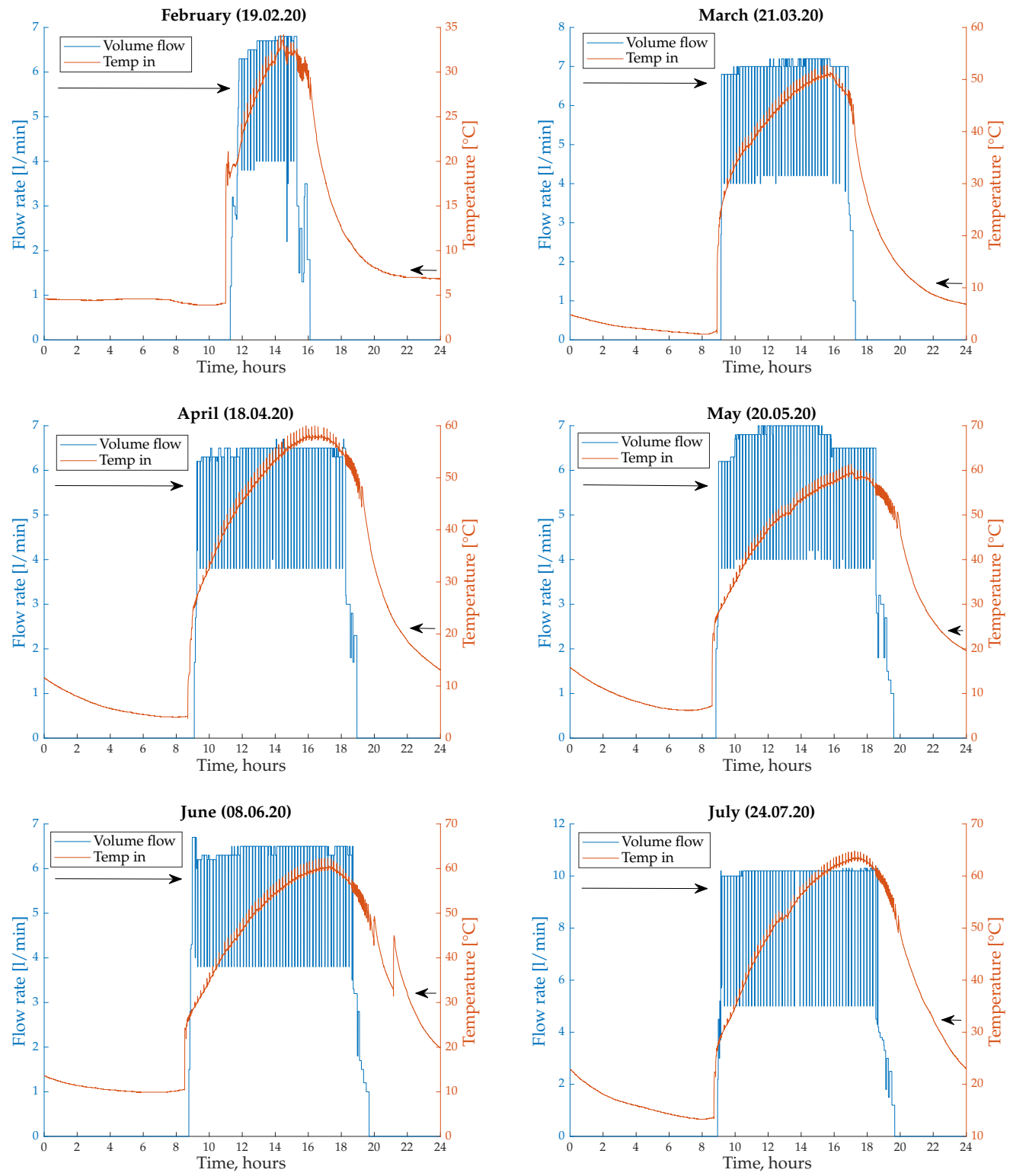

Figure 5. Examples of collector logs for 6 selected dates in February-July.

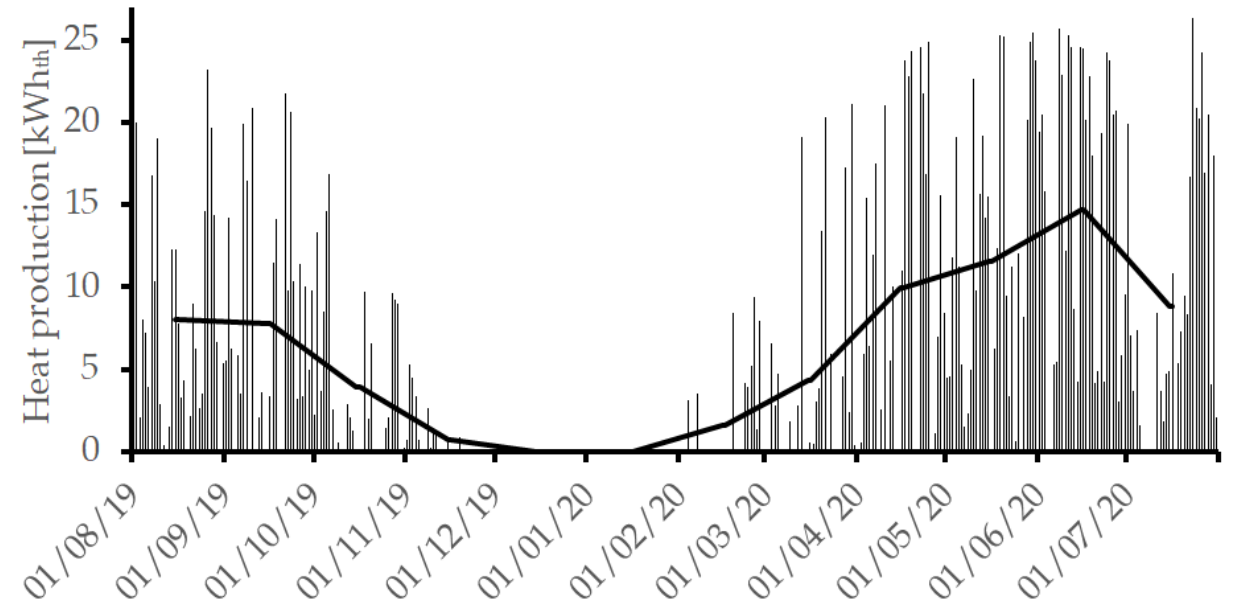

Figure 6. Solar heat generation. 
Table 1. Monthly average collection of solar heat.

\begin{tabular}{ccccccccccccc}
\hline Heat Month & Jan & Feb & Mar & Apr & May & Jun & Jul & Aug & Sep & Oct & Nov & Dec \\
\hline $\bar{H}\left[\mathrm{kWh}_{t h}\right]$ & 0.0 & 1.6 & 4.4 & 10.0 & 11.6 & 14.7 & 8.9 & 8.0 & 7.8 & 3.9 & 0.7 & 0.0 \\
\hline$\sigma\left[\mathrm{kWh}_{t h}\right]$ & 0.0 & 2.9 & 6.6 & 9.3 & 8.4 & 9.0 & 7.7 & 6.7 & 7.1 & 4.9 & 1.6 & 0.0 \\
\hline
\end{tabular}

Using Table 1, we demonstrate that the amount of heat produced by collectors in spring compares to the data for summer. Namely, the average amount of heat produced in April was higher than in July or August. In the table we also present the standard deviation of the data:

$$
\sigma=\sqrt{1 / N \sum_{i=1}^{N}\left(H_{i}-\bar{H}\right)^{2}} .
$$

The standard deviation is comparable in the spring and the summer seasons. The maximum solar heat generation is observed in June. A sudden reduction in solar heating is observed in October. The amount of heat goes below $5 \mathrm{kWh}_{t h}$, and solar production turns to zero in January. The generation is unstable, and the relative dispersion of data is above $100 \%$ for a period until April. The total annual heat generation was $2200 \mathrm{kWh}_{t h}$.

The instantaneous thermal efficiency of the vacuum tubes was measured as $71-72 \%$ in June-July (see Figure 7). Due to the increased insolation in summer, and due to the reflection from the ground and the respective irradiation of the tubes' bottom side, this value was about $10 \%$ over the steady-state efficiency. The year-average instantaneous thermal efficiency of the rig was lower than the steady-state efficiency reported for the vacuum tubes. The maximum difference between the efficiencies was observed in winter when the collectors were at the ambient temperature, and, respectively, $T_{m}=0$. The difference is also seen in the midseason, where the steady-state efficiency becomes $20 \%$ higher than the actual efficiency. Therefore, due to weather conditions' continuous oscillations, the collectors deliver less heat than we calculate for the day-average values of insolation and ambient temperature. This fact must be accounted for when designing solar collector facilities in Scandinavia.

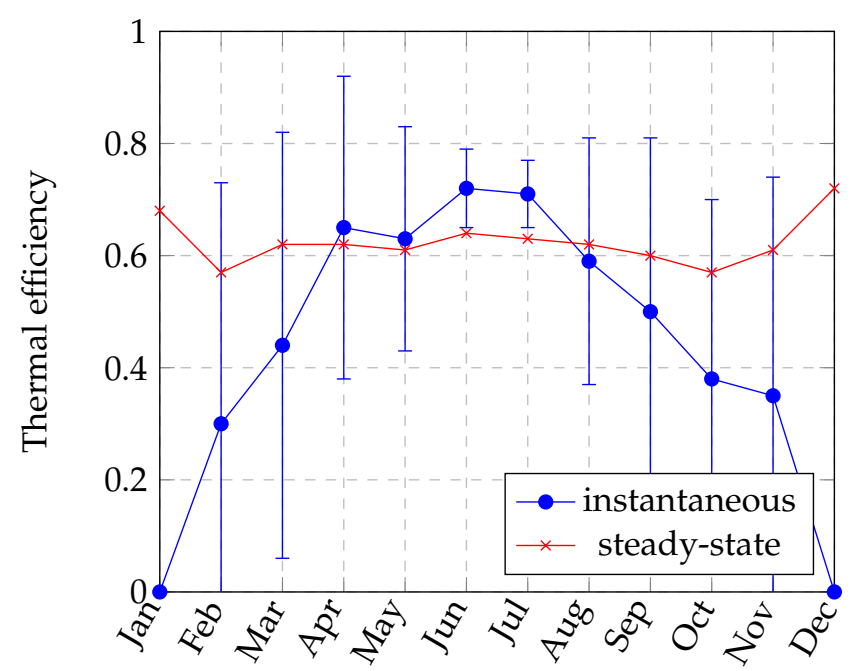

Figure 7. Average thermal efficiency for the controlled period.

It is interesting to evaluate how the collected heat can contribute to a household's overall thermal balance. Downscaling the statistical data from Good et al. [14], we calculate dayaverage heating demand of a standard house in Norway to be $19.6 \mathrm{kWh}$, with $10.4 \mathrm{kWh}_{t h}$ needed for the domestic hot water production. Based on these numbers, we conclude that the vacuum tube facility does not deliver enough heat to cover all household needs in 
winter. However, it is possible to cover the domestic hot water in April-June and prolong this period to September using up to $2.6 \mathrm{kWh}_{t h}$ auxiliary electrical heating. In May-June the collectors produce up to $4.3 \mathrm{kWh}_{t h}$ over the heat that is required for sustainable hot water production. In the present field study, the excessive heat contributes to overheating the greenhouse, so the temperature could rise above $50{ }^{\circ} \mathrm{C}$.

In Figure 8 we demonstrate how the heat is produced due to a 3-fold increase of the solar collector area. The upscaling is technically possible for a typical Norwegian household with an average roof area of $90 \mathrm{~m}^{2}$ [14]. This figure compares the collected solar energy with more detailed statistics of energy consumption from Rekstad et al. [11]. As it follows from the figure, the total consumption of heat is covered in April-September. The domestic hot water demand is covered in March-October. However, the upscaled facility overproduces up to $24.1 \mathrm{kWh}_{t h}$ of heat in summer.

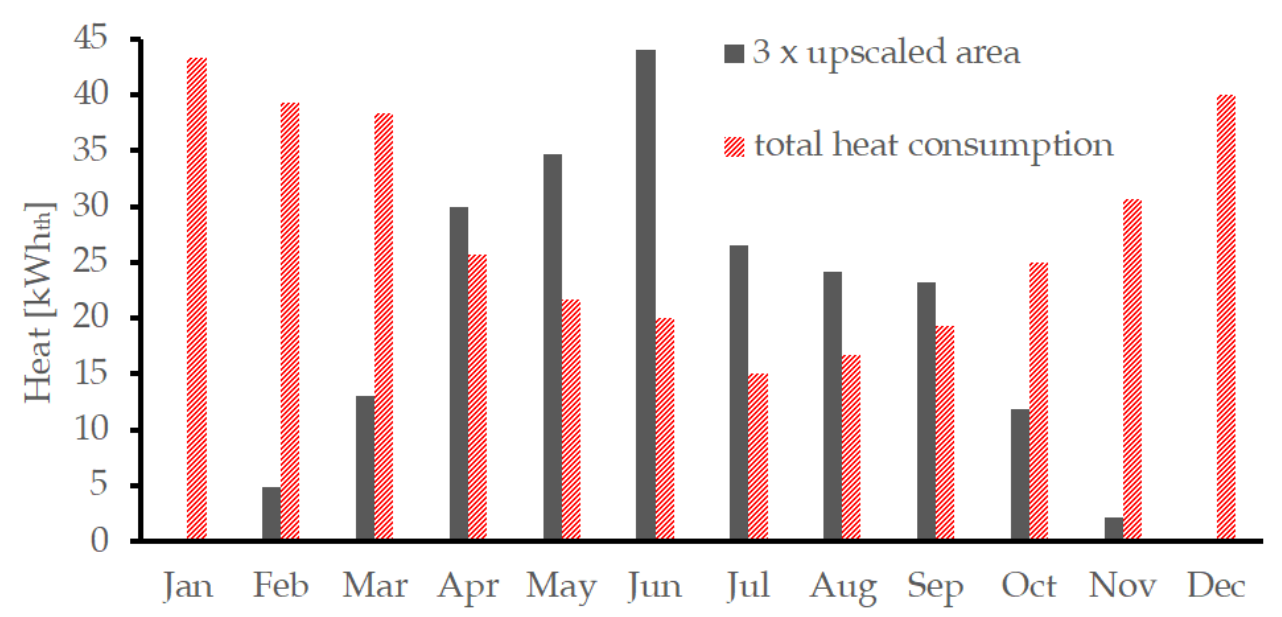

Figure 8. 3x upscaled area daily production of solar heat compared with statistical data on energy consumption [11].

We end the discussion with a brief techno-economical analysis. According to Good et al. [14] and Rekstad et al. [11], an average household consumes $8604 \mathrm{kWh} / \mathrm{y}$. In 2021 prices, electrical heating will cost 860.4 Euro/year. A complete solar collector system with vacuum tubes of $23.4 \mathrm{~m}^{2}$ costs up to 9850 Euro in Norway. The payback period for the collectors becomes 11.5 years. Accounting for the current electricity price, the payback of the solar collector technology in Western Norway is sufficiently lower than the lifetime of collectors set, on average, at 30 years. Therefore, the vacuum tube technology is suitable for Western Norway and may become more attractive when the electricity price grows upon the maturing of the hydropower facilities.

\section{Conclusions}

A year-long experiment on solar heat generation was conducted in Western Norway in the city of Bergen. Bergen has an oceanic climate with plentiful rainfall in all seasons and intermittent snowfall during winter. The commercial vacuum tube solar collectors were used in the study, which demonstrated that the solar thermal technology was suitable for the given climate conditions. The solar collector facility with an area of $7.8 \mathrm{~m}^{2}$ collected up to $25 \mathrm{kWh}_{t h} / \mathrm{d}$ solar heat in summer; this was enough to cover the domestic hot water demand for a typical household with maximal thermal efficiency of $72 \%$. The collectors' year-average thermal efficiency was $44 \%$ which corresponded to a more straightforward flat-plate solar collector system, taken for warmer climate conditions. We, therefore, expect that the flat-plate technology becomes less suitable for the considered conditions as the efficiency of the flat plates may drop down to $20-30 \%$, making them comparable to solar cells. For future studies, this would be relevant to evaluate an opportunity to boost the efficiency of the flat-plate collectors using a nanofluid instead of the glycol solution and 
compare the production with the current results. To our knowledge, there are no field prototypes of the nanofluid-based flat plate collectors available in Scandinavia.

We further conclude that a conservative increase of collector's area to $23.4 \mathrm{~m}^{2}$ will cover the sufficient heat consumption in March-October. In this case, there will be an overproduction of solar heat by $3.9 \mathrm{kWh}_{t h} / \mathrm{d}$ (September) to $24.1 \mathrm{kWh}_{t h} / \mathrm{d}$ (June). It is important to stress that the results for an existing upscaled facility may differ due to increased pumping costs, additional thermal leaks, and different orientation towards the sun, which is the main limitation of the presented analysis. The excessive heat may be accumulated to compensate for the underproduction in winter. The technology of thermal accumulation in a seasonal borehole thermal energy storage (BTES) is widely used in Norway. An auxiliary heat pump is required to extract heat from the wells. There are multiple projects of geothermal storage from domestic engineering companies (Sweco, Ruden etc.). However, there is minimal data available on the thermal properties and thermal regimes of the Norwegian rocks. Therefore, additional studies are required on coupling solar collectors and BTES and synchronize their operation. An optimum heating scenario might also include an installation of $15.6 \mathrm{~m}^{2}$ with auxiliary electrical heating or the use of combined photovoltaic-thermal technology. As it follows from the technoeconomical analysis, the payback period for an upscaled facility with the vacuum tube solar collectors is about 12 years in Western Norway. This is at least twice shorter than the average lifetime of the collectors.

Author Contributions: Conceptualisation, resources and writing, B.V.B. and A.K.; methodology, A.F.O.L.; data analysis, O.N.; investigation, V.P. All authors have read and agreed to the published version of the manuscript.

Funding: The analysis of the statistical data was supported the Russian Science Foundation, project number 19-79-10083. The solar thermal part of the laboratory was funded by the University and College Network for Western Norway (UH-Nett Vest) via the project "Novel solar energy systems for Northern conditions".

Institutional Review Board Statement: Not applicable.

Informed Consent Statement: Not applicable.

Data Availability Statement: Not applicable.

Acknowledgments: The authors thank Kjell Erik Husom from Miløand Energi AS for his contribution in the construction of the facility and Guzel R. Shamsutdinova from HVL for the help with illustrations.

Conflicts of Interest: The authors declare no conflict of interest.

\section{Nomenclature}

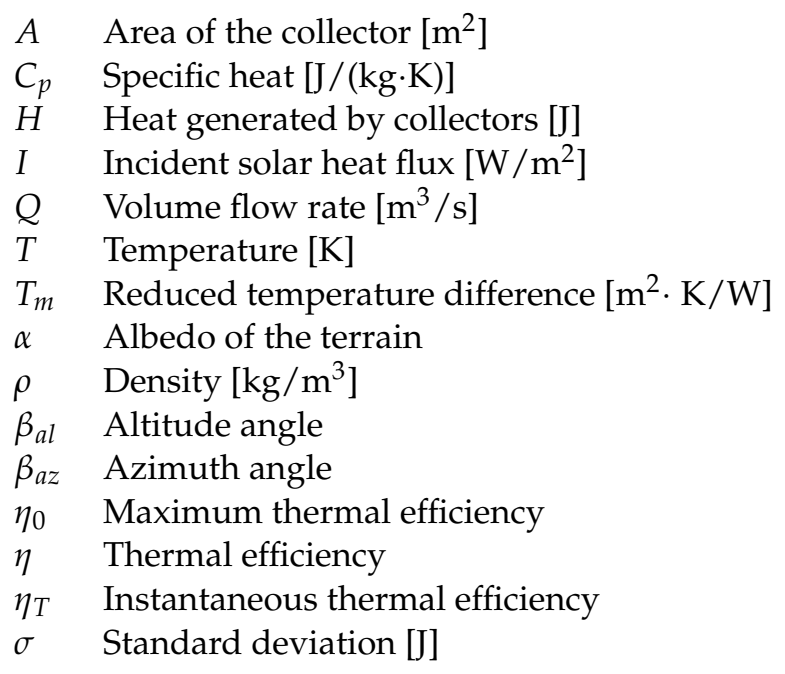




\section{References}

1. Eurostat. Share of Fuels in the Final Energy Consumption in the Residential Sector; Updated 2018; Eurostat: Luxembourg, 2018.

2. Tschopp, D.; Tian, Z.; Berberich, M.; Fan, J.; Perers, B.; Furbo, S. Large-scale solar thermal systems in leading countries: A review and comparative study of Denmark, China, Germany and Austria. Appl. Energy 2020, 270, 114997. [CrossRef]

3. Tian, Z.; Zhang, S.; Deng, J.; Fan, J.; Huang, J.; Kong, W.; Perers, B.; Furbo, S. Large-scale solar district heating plants in Danish smart thermal grid: Developments and recent trends. Energy Convers. Manag. 2019, 189, 67-80. [CrossRef]

4. Olia, H.; Torabi, M.; Bahiraei, M.; Ahmadi, M.H.; Goodarzi, M.; Safaei, M.R. Application of Nanofluids in Thermal Performance Enhancement of Parabolic Trough Solar Collector: State-of-the-Art. Appl. Sci. 2019, 9, 463. [CrossRef]

5. Sarafraz, M.M.; Tlili, I.; Abdul Baseer, M.; Safaei, M.R. Potential of Solar Collectors for Clean Thermal Energy Production in Smart Cities using Nanofluids: Experimental Assessment and Efficiency Improvement. Appl. Sci. 2019, 9, 1877. [CrossRef]

6. Peng, Y.; Zahedidastjerdi, A.; Abdollahi, A.; Amindoust, A.; Bahrami, M.; Karimipour, A.; Goodarzi, M. Investigation of energy performance in a U-shaped evacuated solar tube collector using oxide added nanoparticles through the emitter, absorber and transmittal environments via discrete ordinates radiation method. J. Therm. Anal. Calorim. 2020, 139, 2623-2631. [CrossRef]

7. SSB. Energy Balance by Production and Consumption; Statistisk Sentralbyrå (Statistics Norway): Oslo, Norway, 2020.

8. The Norwegian Water Resources and Energy Directorate. Strømforbruk mot 2040 (in Norwegian). 2019. Available online: https:/ / www.nve.no/ (accessed on 10 May 2021).

9. Hagos, D.A.; Gebremedhin, A.; Zethraeus, B. Solar Water Heating as a Potential Source for Inland Norway Energy Mix. J. Renew. Energy 2014, 2014, 968320. [CrossRef]

10. Norwegian Meteorological Institute. Yr. 2020. Available online: http://www.yr.no/ (accessed on 10 May 2021).

11. Rekstad, J.; Meir, M.; Murtnes, E.; Dursun, A. A comparison of the energy consumption in two passive houses, one with a solar heating system and one with an air-water heat pump. Energy Build. 2015, 96, 149-161. [CrossRef]

12. Meir, M.; Murtnes, E.; Dursun, A.; Rekstad, J. Polymeric solar collectors or heat pump?-Lessons learned from passive houses in Oslo. Energy Procedia 2014, 48, 914-923. [CrossRef]

13. Bernardo, L.R. Retrofitting Conventional Electric Domestic Hot Water Heaters to Solar Water Heating Systems in Single-Family Houses-Model Validation and Optimization. Energies 2013, 6, 953-972. [CrossRef]

14. Good, C.; Andresen, I.; Hestnes, A.G. Solar energy for net zero energy buildings-A comparison between solar thermal, PV and photovoltaic-thermal (PV/T) systems. Sol. Energy 2015, 122, 986-996. [CrossRef]

15. Tamrakar, S.; Mustafa, M.; Riise, R. Feasibility study for utilization of solar energy in the Arctic areas. IOP Conf. Ser. Mater. Sci. Eng. 2019, 700, 012066. [CrossRef]

16. Struchalin, P.; Thon, H.; Kuzmenkov, D.; Kutsenko, K.; Kosinski, P.; Balakin, B. Solar steam generation enabled by iron oxide nanoparticles: Prototype experiments and theoretical model. Int. J. Heat Mass Transf. 2020, 158, 119987. [CrossRef]

17. Bårdsgård, R.; Kuzmenkov, D.M.; Kosinski, P.; Balakin, B. Eulerian CFD model of direct absorption solar collector with nanofluid J. Renew. Sustain. Energy 2020, 12, 033701. [CrossRef]

18. Bergen Kommune. Bergensværet. 2019. Available online: https:/ /www.bergensveret.no/ (accessed on 10 May 2021).

19. University of Bergen. Været i Bergen. 2019. Available online: https://veret.gfi.uib.no/ (accessed on 10 May 2021).

20. TC 312. Thermal Solar Systems and Components—Solar Collectors-Part 2: Test Methods. EN 12975-2: 2006; Comite Europeen de Normalisation: Brussels, Belgium, 2006.

21. Suntask. Solar Thermal Collector. 2020. Available online: http://www.suntask.com/ (accessed on 10 May 2021).

22. Alvarez, M. Ethylene and Propylene Glycol Fluid and Thermal Properties. In Fermilab, Particle Physics Division, Mechanical Department Engineering Note; 2010; Available online: https:/ / webcache.googleusercontent.com/search?q=cache:phrFmFgSCyMJ: https:/ / ppd-docdb.fnal.gov/cgi-bin/RetrieveFile\%3Fdocid\%3D1214\%3Bfilename\%3DMD-ENG-253.pdf\%3Bversion\%3D1+\& $\mathrm{cd}=1 \& \mathrm{hl}=\mathrm{en} \& \mathrm{ct}=\mathrm{clnk} \& \mathrm{gl}=$ no $($ accessed on 11 May 2021). 